\title{
Serada Sonbahar Dönemi Dolmalık Biber Yetiştiriciliğinde Hibrit Çeşit Adaylarının Meyve Kalitesi ve Verim Performansları
}

\section{Fruit Quality and Yield Performance of Hybrid Bell Pepper Cultivar Candidates for Autumn Growing Period in the Greenhouse}

\author{
Rüveyda Özgen ${ }^{1 *}$, Ahmet Balkaya²
}

Geliş / Received: 14/12/2020

Revize / Revised: 14/01/2021

Kabul / Accepted: 18/01/2021

\begin{abstract}
ÖZ
Sebzelerde düşük sıcaklık zararı; büyüme ve gelişmeyi olumsuz etkileyerek verim ve kalite kayıplarına neden olan önemli bir abiyotik stres faktörüdür. Örtüaltı sebze yetiştiriciliğinde düşük sıcaklıklar nedeniyle tür ve çeşitlere göre değişmekle birlikte verim ve kalite performansları yönünden önemli düzeyde azalışlar meydana gelmektedir. $\mathrm{Bu}$ çalışmada, üniversite sanayi iş birliğiyle yürütülen biber çeşit ıslahı programı kapsamında geliştirilen 28 hibrit dolmalık biber çeşit adayının ısıtmasız serada sonbahar dönemi yetiştiriciliğinde meyve kalite ve verim özellikleri yönünden performanslarının karşılaştırılması amaçlanmıştır. Isıtmasız serada ilk hasatlar, fide dikiminden itibaren 46-58 gün sonra yapılmıştır. Dolmalık biber genotipleri arasında meyve boyu değerleri yönünden istatistiksel olarak önemli düzeyde farklılıkların olduğu bulunmuştur. Meyve eni değerleri, 47.31-55.86 mm arasında değişim göstermiştir. Renk tonları yönünden dolmalık biber genotipleri arasında belirgin farklılıkların olduğu saptanmıştır. Hibrit biber çeşit adaylarında bitki başına meyve sayılarının ortalama 15.6-30.0 adet arasında değiştiği belirlenmiş̧ir. Çalışmada, Samsun ekolojik koşullarında serada hibrit biber çeşit adaylarının dekara verim değerlerinin, $2560.5 \mathrm{~kg}$ (HD-16) ile $5102.5 \mathrm{~kg}$ (HD-8) arasında değişim gösterdiği saptanmıştır. Araştırma sonucunda incelenen tüm parametreler birlikte değerlendirildiğinde; HD-4, HD-8 ve HD-24 genotiplerinin düşük sıcaklığa tolerant olduğu ve sonbahar dönemi yetiştiriciliği için ümit var hibrit dolmalık biber çeşit adayları olduğu belirlenmiştir.
\end{abstract}

Anahtar Kelimeler- Biber, Düşük Sicaklık, Isttmasız Sera, Sonbahar, Samsun

\begin{abstract}
Low temperature damage in vegetables is an important abiotic stress factor that negatively affects growth and development, causing yield and quality losses. Due to low temperatures in greenhouse vegetable cultivation, according to the species and varieties significant decreases occur in terms of yield and quality performances. In this study, it was aimed to compare the performance of 28 hybrid bell pepper $F_{1}$ varieties developed within the scope of the pepper variety breeding program carried out in cooperation with the university and industry in terms of fruit quality and yield characteristics in autumn cultivation in the unheated greenhouse. The first harvests were made 46-58 days after the seedling planting in the greenhouse,. It was found that there are statistically significant
\end{abstract}

1*Sorumlu yazar iletişim: rozgen326@gmail.com (https://orcid.org/0000-0001-7641-8751)

Bahçe Bitkileri Bölümü, Ondokuz Mayıs Üniversitesi, Ziraat Fakültesi, Kurupelit Kampüsü Atakum, Samsun

2İletişim: abalkaya@omu.edu.tr (https://orcid.org/0000-0001-9114-615X)

Bahçe Bitkileri Bölümü, Ondokuz Mayıs Üniversitesi, Ziraat Fakültesi, Kurupelit Kampüsü Atakum, Samsun 
differences between bell pepper genotypes in terms of fruit size values. Fruit width values varied between 47.31$55.86 \mathrm{~mm}$. It has been determined that there are significant differences among bell pepper genotypes in terms of colour tones. It was determined that the average number of fruits per plant in hybrid pepper varieties candidates varied between 15.6-30.0 unit. In the study, it was determined that the yield values of hybrid pepper varieties candidates in greenhouse in Samsun ecological conditions varied between $2560.5 \mathrm{~kg} / \mathrm{acre}$ (HD-16) and $5102.5 \mathrm{~kg}$ /acre (HD-8). When all parameters are evaluated together at the end of the research; it was determined that HD-4, HD-8 and HD-24 genotypes are tolerant to low temperature and they are promising hybrid bell pepper varieties candidates for autumn period cultivation.

\section{Keywords- Pepper, Low Temperature, Unheated Greenhouse, Autumn Period, Samsun}

\section{GíRiș}

Biber (Capsicum annuum L.), ülkemizde ve dünyanın birçok farklı bölgesinde yaygın olarak yetiştirilen ve farklı şekillerde tüketime sunulan önemli bir sebze türüdür. Capsicum türleri, tüm tropik ve subtropik iklimlerde yetiştirilebildiği gibi ılıman iklim kuşağında da yaygın olarak yetiştirilmektedir [1]. Biber; taze olarak tüketildiği gibi, kurutulmuş (pul, toz vb.) ve işlenmiş (sos, salça vb.) ürün olarakta değerlendirilmektedir. Ayrıca günümüzde farmakoloji ve kozmetik sanayinde de yaygın olarak kullanılmaktadır [1-3]. Ülkemizde 2019 y1lı biber üretim miktarı değerleri ürün segmentlerine göre incelendiğinde ilk sırayı 1.234.423 ton ile kapya biberin aldığ belirlenmiştir. Bu değeri, 902.203 ton ile sivri biber, 371.918 ton üretim miktarı ile dolmalık biber ve 99.390 ton ile Çarliston biber grubu izlemiştir [4]. Ülkemizde 2019 yılı örtüaltı biber üretim miktarı değeri ise 749.769 tondur ve dolmalık biber grubu bu üretim miktarının \%15'ini oluşturmaktadır [4].

Günümüzde tarımsal üretimde kullanılan modern teknik ve uygulamaların önemli düzeylerde gelişmiş olmasına rağmen, biyotik ve abiyotik stres faktörlerinin etkisiyle tarımda halen önemli düzeylerde verim ve kalite kayıpları meydana gelmektedir. Abiyotik stres faktörlerden birisi olan sıcaklık, yüksek ya da düşük sicaklık şeklinde bitki gelişimini olumsuz yönde etkilemektedir [5]. Düşük sıcaklık stresine karşı bitkiler, gelişme dönemlerine göre farklı tepkiler vermekte, verimlilikleri azalmakta ve ürün kalite ve kantitelerinde önemli düzeyde kayıplar meydana gelmektedir. Sebze yetiştiriciliğinde, bu durum önemli bir tehdit olarak karşımıza çıkmaktadır. Ayrıca sebzelerde düşük sıcaklık zararı; sınırlı iklim koşulları ve dönemlerinde yetiştiricilik yapılmasına neden olmaktadır. Düşük sıcaklık stresine dayanıklılık yönünden bitki türleri arasında çeşit düzeyinde önemli farklılıklar bulunmaktadır. Bu nedenle, son yıllarda hem klasik çeşit ıslah çalışmalarında ve hem de fizyolojik ve moleküler düzeydeki temel araştırmalarda düşük sıcaklık stresine tolerant yeni çeşitlerin geliştirilmesi ve toleranslıkta rol alan mekanizmaların belirlenmesine yönelik bilimsel çalışmalara daha fazla önem verilmeye başlanmıştır. Günümüzde birçok türde dayanıklılık ıslah programları ile düşük sıcaklığa tolerant niteliklere sahip yeni genotiplerin belirlenmesi, nitelikli hatların geliştirilmesi ve ticari olarak tohum üretimlerinin gerçekleştirilmesi büyük bir önem taşımaktadır. Ülkemizde bu içerikte yürütülen sebze çeşit ıslah programlarının sayıları son yıllarda artmaya başlamıştır.

Birçok sebze türü, düşük sıcaklığa hassas olmaları nedeniyle yıl içerisinde dar bir zaman aralığında yetiştirilebilmektedir. $\mathrm{Bu}$ durum arz fazlalığı nedeniyle üreticilerin karlılık düzeylerinin düşmesine neden olmaktadır. Bunun yanı sıra tüketicilerin normal yetiştirme sezonu dışındaki sebze taleplerinin karşılanabilmesi amacıyla, ısıtmalı seralarda üretim yapılması ürün maliyetlerinin daha fazla artış göstermesine neden olmaktadır. Diğer bir önemli husus da üreticilerin, düşük sıcaklık şartlarında bitki gelişimini teşvik etmek için insan sağlığına ve çevreye zarar verme ihtimali olan ilave kimyasal ve büyümeyi düzenleyici maddeleri kullanmasıdır. Belirtilen bu nedenlerden dolayı, ülkemizde düşük sıcaklığa tolerant yeni sebze çeşitlerinin 1slahına yönelik programların oluşturulmasına ihtiyaç vardır. Bu ıslah programları sayesinde, düşük sıcaklığa tolerant yerli sebze çeşitlerinin geliştirilmesi ile hem tohumluk ithalatı azalacak hem de ısıtma masrafı olmadan veya çok az bir masrafla dayanıklı çeşitlerin kullanımı ile daha ucuza ve geniş bir üretim periyodunda (kış dönemi dahil) sebze yetiştiriciliğinin yapılabilmesi mümkün olacaktır.

Biber, büyüme ve gelişme sırasında sıcaklığa çok fazla ihtiyaç duymaktadır. Bir sıcak iklim sebzesi olarak biberin büyüme ve gelişmesi, $25-30^{\circ} \mathrm{C}$ arasındaki sıcaklıklarda optimum olarak meydana gelmektedir [6]. Örtüaltı biber yetiştiriciliğinde başlangıçta seralardaki hava sıcaklığı geceleri yaklaşık $18-20^{\circ} \mathrm{C}$ iken, yetiştiricilikte kritik dönem olan Aralık-Ocak-Şubat aylarında ise $4{ }^{\circ} C^{\prime}$ ye kadar düşmektedir [7]. Kış aylarında seraların 1sıtılması 


\begin{tabular}{|c|c|c|}
\hline & $\begin{array}{l}\text { BŞEÜ Fen Bilimleri Dergisi } \\
8(1), 78-89,2021\end{array}$ & $\begin{array}{r}\text { BSEU Journal of Science } \\
\text { https://doi.org/10.35193/bseufbd.840847 }\end{array}$ \\
\hline & & 2458-7575 (https://dergipark.org.tr/tr/pub/bseufbd) \\
\hline
\end{tabular}

üretim maliyetini artırdığından, ülkemizdeki seralarda biber yetiştiriciliği don tehlikesinin olduğu çok soğuk günler dışında genellikle ısıtmasız olarak yapılmaktadır. Düşük gece sıcaklıkları, biber fidelerinde kalın ve küçük yaprakların oluşmasına ve bitkilerin daha kısa boylu olarak gelişmesine neden olmaktadır [8]. Biberde, düşük sıcaklık $\left(14{ }^{\circ} \mathrm{C}\right.$ ve altı) ve düşük ışık yoğunluğu nedeniyle dişi organların işlevi bozulmakta, yeterli miktarda çiçek tozu oluşmamakta, oluşan çiçek tozlarının canlılıkları düşmekte ve çimlenme yetenekleri azalmaktadır [9]. Polen deformasyonları, meyve iriliği ve kalitesinde kayıplar meydana getirmektedir [10]. Bu ise halk arasında "takoz meyve" olarak bilinen küçük ve sert meyve oluşumudur. Sonuçta verim unsurları ve ürün kalitesinde önemli düzeyde azalışlar meydana gelmektedir [11]. Biberde, genel olarak $16^{\circ} \mathrm{C}$ 'nin altındaki sıcaklıklarda meyve tutumu gerçekleşmemekte ve bunun sonucunda verim potansiyeli azalış göstermektedir [3]. İyi bir meyve tutumu için çiçeklenme aşamasında gece sıcaklığının $15^{\circ} \mathrm{C}$ 'nin altına düşmemesi gerekmektedir. Gece sıcaklığı düşük olduğunda, partenokarpik biber meyveleri meydana gelmektedir. Serada ortam sıcaklığ $5{ }^{\circ} \mathrm{C}$ 'nin altına düştüğünde ve 1sıtma yapılmadığı takdirde ise bitkilerin hayati fonksiyonlarında belirgin olarak azalışlar meydana gelmektedir. Ayrıca, $0^{\circ} \mathrm{C}^{\prime}$ nin altındaki uzun süreli soğuklarda biber yetiştiriciliğinde bitki ölümleri ile karşılaşılmaktadır.

Düşük sıcaklık stresine dayanıklılık yönünden sebze türleri arasında genotipik düzeyde farklılıklar bulunmaktadır. Bazı genotipler; hücre membranlarının lipit bileşimlerinde, çözülebilir maddelerde, bitki besin elementlerinde ve protein miktarlarında değişimler gerçekleştirerek ya da antioksidant enzim sistemlerini aktive ederek düşük sıcaklık sürecine karşı toleranslık sağlayabilmektedirler [12]. Bu nedenle, çeşit dayanıklılık sslah programları ile düşük sıcaklık stresine dayanıklı genotiplerin belirlenmesi, tolerans mekanizmalarının açıklanması, dayanıklı genetik kaynaklarının korunması ve diğer türlere dayanaklılığın aktarılmasına yönelik araştırmaların yapılması büyük bir önem taşımaktadır. Bu çalışmada, üniversite ve özel sektör işbirliği kapsamında Türkiye'nin yerli dolmalık biber genetik kaynakları kullanılarak geliştirilen düşük sıcaklığa tolerant, yerli hibrit biber çeşit adaylarının ısıtmasız serada sonbahar dönemi yetiştiriciliğinde meyve kalite unsurları ve verimlilik performansları yönünden incelenmesi amaçlanmıştır.

\section{MATERYAL VE METOT}

Çalışma, Samsun ekolojik koşullarında Eylül 2018-Aralık 2018 tarihleri arasındaki dönemde yürütülmüştür. Araştırmanın arazi çalışmaları, Ondokuz Mayıs Üniversitesi Ziraat Fakültesi Araştırma ve Uygulama Serasında gerçekleştirilmiştir. Laboratuvar çalışmaları ise Bahçe Bitkileri Bölümü Fizyoloji laboratuvarında yürütülmüştür. Bitkisel materyal olarak, OMÜ BAP 1903-Sanayi İşbirliği Araştırma Projeleri kapsamında tür içi melezleme sslah programı sonucunda geliştirilen düşük sıcaklığa tolerant 28 adet dolmalık biber çeşit adayı kullanılmıştır (Tablo 1). Ayrıca kontrol çeşit olarak düşük sıcaklığa dayanımı tolerant olarak bildirilen Benino $F_{1}$ dolmalık biber çeşidi kullanılmıştır.

Tablo 1. Düşük sıcaklığa tolerant dolmalık biber genotiplerinin oluşturulmasına yönelik oluşturulan tür içi melez kombinasyonlarına ait kayıt bilgileri

\begin{tabular}{|c|c|c|c|c|c|c|c|}
\hline Kod Numarası & $\begin{array}{c}\text { Ana } \\
\text { Ebeveyn }\end{array}$ & $\mathbf{X}$ & Baba Ebeveyn & $\begin{array}{c}\text { Kod } \\
\text { Numarası }\end{array}$ & Ana Ebeveyn & $\mathbf{X}$ & Baba Ebeveyn \\
\hline HD1 & EF119 & $\mathrm{X}$ & PB60 & HD15 & PB75 & $X$ & EF261 \\
\hline HD2 & EF153 & $\mathrm{X}$ & PB60 & HD16 & PB75 & $\mathrm{X}$ & EF321 \\
\hline HD3 & EF164 & $\mathrm{X}$ & PB60 & HD17 & PB75 & $\mathrm{X}$ & EF365 \\
\hline HD4 & PB90 & $\mathrm{X}$ & EF683 & HD18 & PB75 & $\mathrm{X}$ & EF393 \\
\hline HD5 & EF171 & $\mathrm{X}$ & PB60 & HD19 & PB75 & $\mathrm{X}$ & EF407 \\
\hline HD6 & EF292 & $X$ & PB60 & HD20 & PB75 & $X$ & EF683 \\
\hline HD7 & EF303 & $X$ & PB60 & HD21 & PB77 & $X$ & EF119 \\
\hline HD8 & EF473 & $\mathrm{X}$ & PB60 & $\mathrm{HD} 22$ & PB90 & $\mathrm{X}$ & EF153 \\
\hline HD9 & EF502 & $X$ & PB60 & HD23 & PB90 & $X$ & EF168 \\
\hline HD10 & EF627 & $\mathrm{X}$ & PB60 & $\mathrm{HD} 24$ & PB90 & $\mathrm{X}$ & EF261 \\
\hline HD11 & PB61 & $\mathrm{X}$ & EF393 & HD25 & PB90 & $\mathrm{X}$ & EF321 \\
\hline HD12 & PB75 & $X$ & EF119 & HD26 & PB90 & $X$ & EF365 \\
\hline HD13 & PB75 & $X$ & EF164 & HD27 & PB90 & $X$ & EF393 \\
\hline HD14 & PB75 & $X$ & EF168 & HD28 & PB90 & $X$ & EF407 \\
\hline
\end{tabular}


Serada dikim öncesinde, 0-30 cm derinlikten toprak analizi için örnekler alınmıştır. Toprak analizleri, Karadeniz Tarımsal Araştırma Enstitüsü Toprak Analiz Laboratuvarında yaptırılmıştır [13]. Toprak yapısının killi, pH'ının nötr, organik madde miktarının ise yüksek olduğu tespit edilmiştir. Ayrıca deneme arazisinde toprak tuzluluğu ve kireç miktarının az, fosfor ile potasyum içeriği yönünden de oldukça yüksek olduğu belirlenmiş̧tir. Hibrit dolmalık biber genotiplerine ait tohum ekimleri, Antalya'da bulunan Genetika Tohumculuk Tarım Sanayi ve Ticaret Limited Şirketine ait fide üretim serasında 3:1 oranında torf ve perlit karışımı ile hazırlanan ortamla doldurulmuş olan viyollere yapılmıştır. Dolmalık biber fideleri, $3-4$ gerçek yapraklı döneme kadar $25 \pm 2{ }^{\circ} \mathrm{C}$ sıcaklık değerine sahip kontrollü serada yetiştirilmiştir. Düşük sıcaklığa tolerant, güçlü kök yapısı olan hibrit dolmalık biber çeşit adaylarının ısıtmasız serada fide dikimleri, her tekerrürde 6 bitki olacak şekilde 3 tekerrürlü olarak tesadüf blokları deneme desenine göre 31.08.2018 tarihinde yapılmıştır. Sera içerisindeki sıcaklık ve oransal nem değerleri "Datalogger ölçüm cihazı" ile günlük olarak ölçülmüştür (Şekil 1, Şekil 2). Dikim işleminden sonra serada yetiştirilen bitkilere toprak analiz sonuçlarına göre gübreleme programı uygulanmıştır. Ayrıca diğer kültürel işlemler de (budama, ilaçlama vb. ) düzenli olarak yapılmıştır.

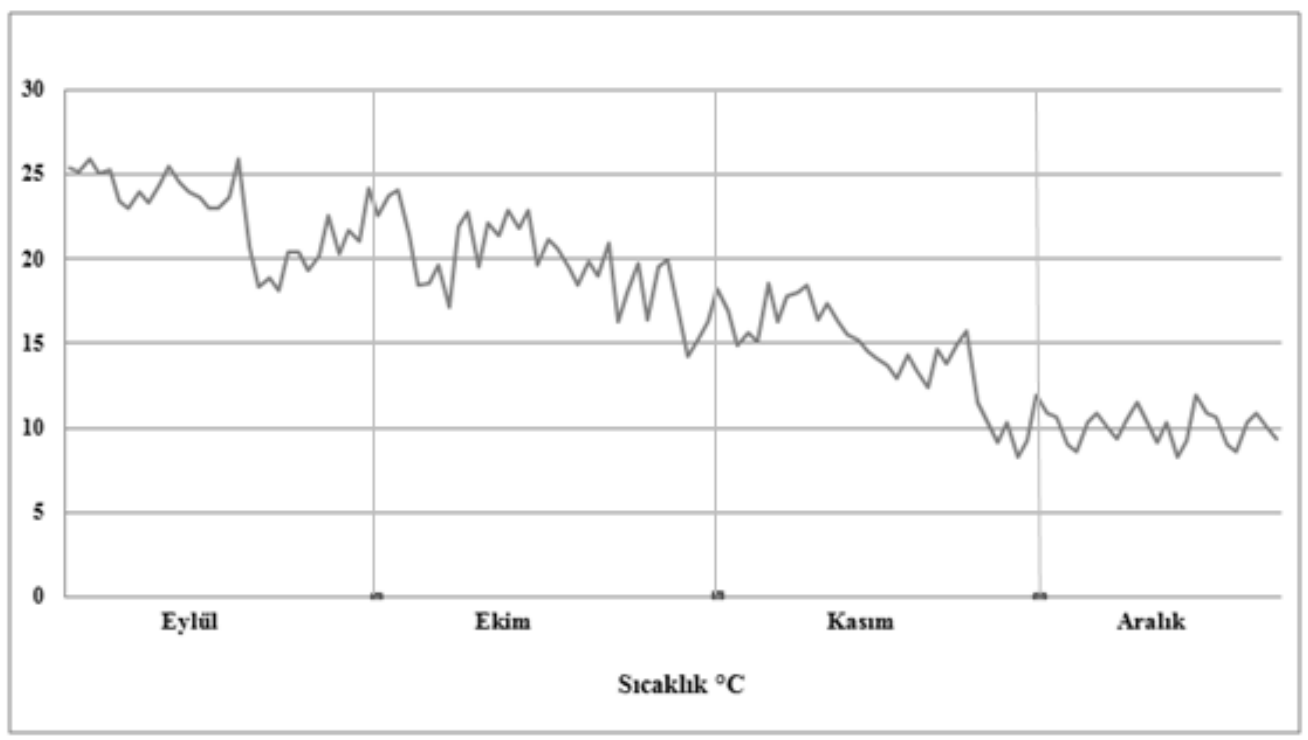

Şekil 1. Isıtmasız serada Eylül-Aralık yetiştirme dönemine ait ortalama sıcaklık değerlerinin günlük değişimleri

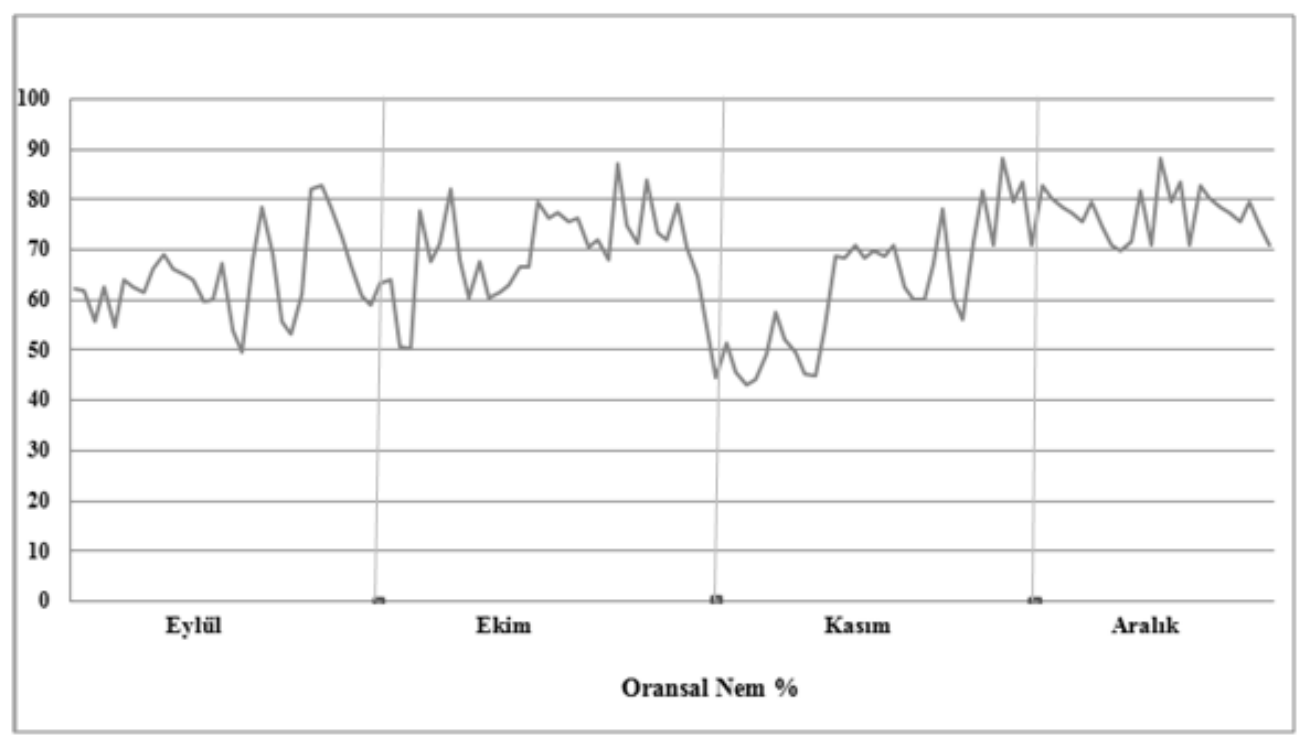

Şekil 2. Isıtmasız serada Eylül-Aralık yetiştirme dönemine ait ortalama oransal nem değerlerinin günlük değişimleri 
Çalışmada hibrit dolmalık biber çeşit adaylarının ilk çiçeklenme süresi (gün), ilk hasat zamanı (gün) ve hasat periyodu gibi fenolojik gözlemler yapılmıştır. Biber genotiplerinde meyve kalite özelliklerinin belirlenmesi amacıyla aşağıdaki özellikler incelenmiştir.

1. Ortalama meyve boyu (mm): Her genotipte hasat edilen meyvelerde meyve uzunlukları dijital kumpas yardımıyla ölçülüp, ortalamaları alınmıştır.

2. Ortalama meyve eni (mm): Hasat edilen meyvelerin eni, dijital kumpas yardımıyla ölçülmüştür.

3. Meyve şekil indeksi: Her genotipte meyvelerin boy/en değerleri hesaplanarak meyve şekil indeksi katsayıları belirlenmiştir.

4. Meyve sap uzunluğu (mm): Her genotipte hasat edilen meyvelerde meyve sap uzunlukları, dijital kumpas yardımıyla ölçülmüştür.

5. Meyve rengi: Görsel olarak koyu yeşil, yeşil, açık yeşil ve sarı olarak belirlenmiştir. Dijital olarak, Minolta CR-410 tristimulus renk ölçer aleti kullanılarak meyvenin karşılıklı olarak iki bölgesinden yapılmıştır. Minolta Chronomometre renk ölçüm aleti ile meyve renk yoğunluklarının değerlendirilmesi; L: Parlaklık oranı, +a: Kırmızı, -a: Yeşil, +b: Sarı, -b: Mavi skalasına göre yapılmıştır.

6. Meyve et kalınlığı (mm): Her genotipte hasat edilen meyvelerde, meyve eti kalınlığını çekirdek evinin bittiği noktadan başlanarak meyve et kısmının tamamı dijital kumpas yardımıyla ölçülmüştür.

7. Ortalama kuru madde miktarı (g): Her genotipten hasat edilen meyve örneklerinin, kuru madde miktarlarının belirlenmesi amacıyla $80^{\circ} \mathrm{C}$ 'de 72 saat süreyle etüvde kurutulmuştur [2]. Daha sonra meyve kuru ağırlıkları, hassas terazi $(0.001 \mathrm{~g})$ kullanılarak belirlenmiştir.

Meyve hasatları, hibrit çeşit adaylarının meyve olgunlaşmasına bağlı olarak beş gün aralıklarla kademeli olarak yapılmıştır. Hibrit dolmalık biber genotiplerinde verim performanslarının belirlenmesi amacıyla aşağıdaki özellikler incelenmiştir.

1. Meyve sayısı/bitki (Adet): Hasat dönemi içinde her bir bitkiden hasat edilen toplam meyve sayıları belirlenmiştir.

2. Toplam meyve ağırlı̆̆ $/$ bitki $(\mathrm{g})$ : Hasat dönemi içinde her bir bitkiden hasat edilen tüm meyvelerin ağırlıkları hassas terazi (0.001 g) kullanılarak saptanmıştır.

3. Ortalama meyve ağırlığı (g): Her bitkiden hasat edilen tüm meyvelerin toplam ağırlığının, toplam meyve sayısına oranlanması ile ortalama meyve ağırlığı değerleri belirlenmiştir.

4. Toplam verim $(\mathrm{kg} / \mathrm{da})$ : Her hasatta alınan verim değerleri birleştirilerek toplam verim miktarları tespit edilmiştir.

Araştırma sonucunda elde edilen tüm veriler, JMP 5.01 istatistik programında varyans analizine tabi tutulmuş ve Duncan çoklu karşılaştırma sistemine göre benzerlik ve farklılık gruplandırmaları yapılmıştır.

\section{BULGULAR VE TARTIŞMA}

Araştırmada, Samsun ekolojik koşullarında sonbahar döneminde hibrit dolmalık biber çeşit adaylarında ilk çiçeklenme tarihleri, genotiplere göre değişmekle birlikte en erken, HD-20 (15.8 gün, 16 Eylül) genotipinde ve en geç çiçeklenme ise HD-23 (30.8 gün, 1 Ekim) genotipinde tespit edilmiştir (Tablo 2). Literatürde, Asi $F_{1}$ ve Görkem $F_{1}$ biber çeşitlerinin 43-48 gün arasında ilk çiçeklenmeye ulaştıklarını bildirilmiştir [14]. Başka bir çalışmada ise 185 farklı biber genotipinde tohum ekiminden itibaren ilk çiçeklenme tarihlerinin 19-55 gün arasında değiştiği tespit edilmiştir [15]. Araştırma sonuçları ile literatürlerde belirtilen çiçeklenme süreleri arasındaki farklılıklar genel olarak ekoloji ve biber genotipleri arasındaki genetik çeşitlilikten kaynaklanmaktadır.

Dolmalık biber çeşit adaylarında olgunlaşma süresi, genotiplere ve çevre koşullarına bağlı olarak değişkenlik göstermiştir. Araştırma sonucunda, Samsun'da sonbahar döneminde, 1sıtmasız serada yapılan yetiştiricilikte dolmalık biber çeşit adaylarında ilk hasat sürelerinin 46 ile 58 gün arasında gerçekleştiği tespit edilmiştir (Tablo 2). Literatürde farklı dolmalık biber çeşitlerinde ilk hasat tarihinin 47-53 gün arasında değiştiği bildirilmiştir [16]. Bu çalışmada, en son hasat işlemi 20 Aralık 2018 tarihinde yapılmıştır. Dolmalık biber 
genotiplerinde en kısa hasat periyodu 47.1 gün ile HD-6 genotipinde, en uzun hasat periyodu ise 65.0 gün ile HD12 genotipinde kaydedilmiştir (Tablo 2).

Hibrit dolmalık biber çeşit adaylarının meyve boyu, meyve eni, meyve sap uzunluğu ve meyve şekil indeksine ait ayrıntılı sonuçlar, Tablo 3'de verilmiştir. Dolmalık biber genotipleri arasında meyve boyu değerleri yönünden istatistiksel olarak önemli düzeyde farklılıkların olduğu bulunmuştur. Dolmalık biber genotiplerinde ortalama meyve boyu değerlerinin, 59.63-76.93 mm arasında dağılış gösterdikleri belirlenmiştir. En uzun meyve boyu, $76.93 \mathrm{~mm}$ ile HD-8 genotipi ve en kısa meyve boyu ise $59.63 \mathrm{~mm}$ ile HD-6 genotipine ait meyvelerde ölçülmüştür. Farklı araştırıcılar tarafindan yapılan çalışmalarda, dolmalık biber genotiplerinde meyve uzunluğunun 5.0-8.4 cm arasında [16] veya 5.8-6.6 cm arasında değişim gösterdikleri bildirilmiştir [17]. Araştırma sonuçları, belirtilen literatürleri destekler nitelikte olmuştur.

Tablo 2. Dolmalık biber genotiplerinde ilk çiçeklenme (gün) ve ilk hasat süreleri (gün) ile hasat periyotları (gün)

\begin{tabular}{|c|c|c|c|}
\hline $\begin{array}{l}\text { Genotip } \\
\text { No }\end{array}$ & $\begin{array}{c}\text { İlk Çiçeklenme } \\
\text { Süresi (gün) }\end{array}$ & $\begin{array}{c}\text { İlk Hasat Süresi } \\
\text { (gün) }\end{array}$ & $\begin{array}{c}\text { Hasat Periyodu } \\
\text { (gün) }\end{array}$ \\
\hline HD-1 & $27.8 \mathrm{a}-\mathrm{c}$ & 52.8 a-e & $53.1 \mathrm{~d}-\mathrm{h}$ \\
\hline HD-2 & $25.1 \mathrm{a}-\mathrm{f}$ & $52.3 \mathrm{~b}-\mathrm{e}$ & $56.1 \mathrm{~b}-\mathrm{e}$ \\
\hline HD-3 & $23.6 \mathrm{~b}-\mathrm{g}$ & $50.8 \mathrm{~b}-\mathrm{g}$ & $60.1 \mathrm{a}-\mathrm{d}$ \\
\hline HD-4 & $21.8 \mathrm{c}-\mathrm{h}$ & $51.8 \mathrm{~b}-\mathrm{f}$ & $59.1 \mathrm{a}-\mathrm{d}$ \\
\hline HD-5 & $29.0 \mathrm{ab}$ & $56.0 \mathrm{ab}$ & $47.5 \mathrm{gh}$ \\
\hline HD-6 & $24.8 \mathrm{a}-\mathrm{f}$ & $53.8 \mathrm{a}-\mathrm{d}$ & $47.1 \mathrm{~h}$ \\
\hline HD-7 & $26.3 \mathrm{a}-\mathrm{d}$ & $53.6 \mathrm{a}-\mathrm{d}$ & $54.8 \mathrm{~b}-\mathrm{h}$ \\
\hline HD-8 & 25.0 a-f & $50.3 \mathrm{~b}-\mathrm{g}$ & $58.1 \mathrm{a}-\mathrm{e}$ \\
\hline HD-9 & $23.0 \mathrm{~b}-\mathrm{g}$ & $54.5 \mathrm{a}-\mathrm{c}$ & $54.0 \mathrm{c}-\mathrm{h}$ \\
\hline HD-10 & $22.1 \mathrm{c}-\mathrm{h}$ & $52.6 \mathrm{~b}-\mathrm{e}$ & $53.3 \mathrm{~d}-\mathrm{h}$ \\
\hline HD-11 & $21.8 \mathrm{~d}-\mathrm{h}$ & $51.0 \mathrm{~b}-\mathrm{g}$ & $57.5 \mathrm{a}-\mathrm{e}$ \\
\hline HD-12 & $18.8 \mathrm{f}-\mathrm{h}$ & $46.0 \mathrm{~g}$ & $65.0 \mathrm{a}$ \\
\hline HD-13 & $20.6 \mathrm{~d}-\mathrm{h}$ & $51.3 \mathrm{~b}-\mathrm{g}$ & $54.6 \mathrm{~b}-\mathrm{h}$ \\
\hline HD-14 & $28.6 \mathrm{ab}$ & $52.1 \mathrm{~b}-\mathrm{e}$ & $56.3 \mathrm{~b}-\mathrm{e}$ \\
\hline HD-15 & $24.0 \mathrm{~b}-\mathrm{f}$ & $50.0 \mathrm{c}-\mathrm{g}$ & $56.0 \mathrm{~b}-\mathrm{f}$ \\
\hline HD-16 & 24.6 a-f & $49.7 \mathrm{c}-\mathrm{g}$ & 57.6 a-e \\
\hline HD-17 & $21.1 \mathrm{~d}-\mathrm{h}$ & $52.3 \mathrm{~b}-\mathrm{e}$ & $56.1 \mathrm{~b}-\mathrm{e}$ \\
\hline HD-18 & $19.8 \mathrm{e}-\mathrm{h}$ & $48.5 \mathrm{~d}-\mathrm{g}$ & $55.0 \mathrm{~b}-\mathrm{h}$ \\
\hline HD-19 & $22.1 \mathrm{c}-\mathrm{h}$ & $51.0 \mathrm{~b}-\mathrm{g}$ & 60.0 a-d \\
\hline HD-20 & $15.8 \mathrm{~h}$ & $46.0 \mathrm{~g}$ & $62.5 \mathrm{ab}$ \\
\hline HD-21 & $22.6 \mathrm{~b}-\mathrm{g}$ & $48.5 \mathrm{~d}-\mathrm{g}$ & $50.0 \mathrm{e}-\mathrm{h}$ \\
\hline HD-22 & $17.5 \mathrm{~g}-\mathrm{h}$ & $47.5 \mathrm{e}-\mathrm{g}$ & $56.0 \mathrm{~b}-\mathrm{f}$ \\
\hline HD-23 & $30.8 \mathrm{a}$ & $58.3 \mathrm{a}$ & $47.6 \mathrm{f}-\mathrm{h}$ \\
\hline HD-24 & $23.8 \mathrm{~b}-\mathrm{g}$ & $51.0 \mathrm{~b}-\mathrm{g}$ & $60.0 \mathrm{a}-\mathrm{d}$ \\
\hline HD-25 & 25.8 a-e & $55.0 \mathrm{a}-\mathrm{c}$ & $56.0 \mathrm{~b}-\mathrm{f}$ \\
\hline HD-26 & $27.8 \mathrm{a}-\mathrm{c}$ & $53.5 \mathrm{a}-\mathrm{d}$ & $55.0 \mathrm{~b}-\mathrm{h}$ \\
\hline HD-27 & $17.5 \mathrm{~g}-\mathrm{h}$ & $46.5 \mathrm{f}-\mathrm{g}$ & $62.0 \mathrm{a}-\mathrm{c}$ \\
\hline HD-28 & $26.5 \mathrm{a}-\mathrm{d}$ & $55.3 \mathrm{a}-\mathrm{c}$ & $55.6 \mathrm{~b}-\mathrm{g}$ \\
\hline Benino $F_{1}$ & $31.0 \mathrm{a}$ & $58.3 \mathrm{a}$ & $50.1 \mathrm{e}-\mathrm{h}$ \\
\hline $\mathbf{P}$ & $<0.05$ & $<0.05$ & $<0.05$ \\
\hline
\end{tabular}

Dolmalık biber genotiplerinde meyve eni değerleri, ortalama 47.31-55.86 mm arasında değişim göstermiştir. En geniş meyve eni, HD-5 (55.86 mm) genotipinde ölçülmüştür. Bunu sırasıyla HD-6 (54.10 mm) ve HD-12 (54.08 mm) genotipleri izlemiştir. Meyve eni en dar olan biber genotipleri ise istatistiksel olarak aynı grupta yer alan HD-18 (47.31 mm), HD-27 (47.46 mm) ve HD-19 (47.52 mm) olarak tespit edilmiştir. Kontrol Benino $\mathrm{F}_{1}$ çeşidinde ise meyve eni, ortalama $52.28 \mathrm{~mm}$ olarak ölçülmüştür. Literatürde farklı dolmalık biber çeşitlerinde meyve eni değerinin 4.7-4.9 cm arasında değiştiği bildirilmiştir ([16]. Başka bir çalışmada ise dolmalık biber genotiplerinde ortalama meyve eni değerinin 4.7-6.8 cm arasında değişim gösterdiği tespit edilmiştir [17].

Araştırmada biber genotiplerinde meyve boyu değerleri meyve eni değerlerine oranlanarak meyve şekil indeksi katsayıları hesaplanmıştır. Çalışma sonucunda, HD-8 genotipinin (1.61) en yüksek meyve şekil indeksine ve HD-12 genotipinin ise (1.11) en düşük meyve şekil indeksi katsayısına sahip olduğu saptanmıştır (Tablo 3). Araştırmada kontrol olarak yer alan Benino $F_{1}$ çeşidinin meyve şekil indeksinin ise 1.33 olduğu tespit edilmiştir. Meyve şekil indeksi değerlerine göre genotipler arasında istatistiksel olarak farklılık bulunmamıştır. 
Tablo 3. Hibrit dolmalık biber çeşit adaylarının ortalama meyve uzunluğu, meyve sap uzunluğu ve meyve şekil indeksine ait sonuçlar

\begin{tabular}{|c|c|c|c|c|}
\hline $\begin{array}{l}\text { Genotip } \\
\text { No }\end{array}$ & $\begin{array}{l}\text { Meyve Boyu } \\
\text { (mm) }\end{array}$ & $\begin{array}{l}\text { Meyve Eni } \\
\quad(\mathrm{mm})\end{array}$ & $\begin{array}{c}\text { Meyve Sap } \\
\text { Uzunluğu (mm) }\end{array}$ & $\begin{array}{c}\text { Meyve Şekil } \\
\text { İndeksi }\end{array}$ \\
\hline HD-1 & $62.17 \mathrm{~h}-\mathrm{j}$ & $53.08 \mathrm{a}-\mathrm{c}$ & $36.30 \mathrm{~d}-1$ & 1.17 \\
\hline HD-2 & $69.13 \mathrm{c}-\mathrm{g}$ & 50.84 b-f & $39.35 \mathrm{~b}-\mathrm{h}$ & 1.35 \\
\hline HD-3 & $62.68 \mathrm{~g}-\mathrm{j}$ & $50.89 \mathrm{~b}-\mathrm{f}$ & $34.63 \mathrm{~h}-\mathrm{j}$ & 1.23 \\
\hline HD-4 & $69.51 \mathrm{~b}-\mathrm{f}$ & $49.60 \mathrm{c}-\mathrm{f}$ & $36.37 \mathrm{~d}-1$ & 1.40 \\
\hline HD-5 & $63.61 \mathrm{e}-\mathrm{j}$ & $55.86 \mathrm{a}$ & $34.99 \mathrm{~g}-\mathrm{j}$ & 1.13 \\
\hline HD-6 & $59.63 \mathrm{j}$ & $54.10 \mathrm{ab}$ & $30.72 \mathrm{j}$ & 1.10 \\
\hline HD-7 & $69.13 \mathrm{c}-\mathrm{h}$ & $50.45 b-f$ & $36.71 \mathrm{~d}-1$ & 1.37 \\
\hline HD-8 & $76.93 \mathrm{a}$ & 47.57 ef & 41.07 a-e & 1.61 \\
\hline HD-9 & $71.61 \mathrm{a}-\mathrm{d}$ & $49.41 \mathrm{c}-\mathrm{f}$ & $38.08 \mathrm{~b}-\mathrm{h}$ & 1.44 \\
\hline HD-10 & 70.04 b-e & $47.96 \mathrm{ef}$ & 37.88 b-h & 1.46 \\
\hline HD-11 & $70.65 \mathrm{a}-\mathrm{d}$ & $49.28 \mathrm{c}-\mathrm{f}$ & $38.97 \mathrm{~b}-\mathrm{h}$ & 1.43 \\
\hline HD-12 & $60.38 \mathrm{ij}$ & $54.08 \mathrm{ab}$ & $39.51 \mathrm{~b}-\mathrm{g}$ & 1.11 \\
\hline HD-13 & $67.15 \mathrm{c}-1$ & $49.82 \mathrm{c}-\mathrm{f}$ & $36.94 \mathrm{c}-1$ & 1.34 \\
\hline HD-14 & $63.74 \mathrm{e}-\mathrm{j}$ & $49.25 \mathrm{c}-\mathrm{f}$ & $32.05 \mathrm{ij}$ & 1.29 \\
\hline HD-15 & $69.33 \mathrm{~b}-\mathrm{g}$ & $50.15 \mathrm{c}-\mathrm{f}$ & $38.11 \mathrm{~b}-\mathrm{h}$ & 1.38 \\
\hline HD-16 & $63.12 \mathrm{f}-\mathrm{j}$ & $50.06 \mathrm{c}-\mathrm{f}$ & $39.80 \mathrm{~b}-\mathrm{g}$ & 1.26 \\
\hline HD-17 & $70.06 \mathrm{~b}-\mathrm{e}$ & $49.54 \mathrm{c}-\mathrm{f}$ & $41.92 \mathrm{a}-\mathrm{c}$ & 1.41 \\
\hline HD-18 & $75.95 \mathrm{ab}$ & $47.31 \mathrm{f}$ & $40.10 \mathrm{~b}-\mathrm{f}$ & 1.60 \\
\hline HD-19 & $70.84 \mathrm{a}-\mathrm{d}$ & $47.52 \mathrm{f}$ & $35.77 \mathrm{f}-\mathrm{j}$ & 1.49 \\
\hline HD-20 & $69.90 \mathrm{~b}-\mathrm{e}$ & $50.00 \mathrm{c}-\mathrm{f}$ & $39.19 \mathrm{~b}-\mathrm{h}$ & 1.39 \\
\hline HD-21 & $67.33 \mathrm{c}-\mathrm{h}$ & $52.16 \mathrm{a}-\mathrm{d}$ & $42.82 \mathrm{ab}$ & 1.29 \\
\hline HD-22 & $66.31 \mathrm{~d}-\mathrm{j}$ & $51.41 \mathrm{~b}-\mathrm{e}$ & $42.51 \mathrm{ab}$ & 1.29 \\
\hline HD-23 & 72.48 a-d & $51.45 \mathrm{~b}-\mathrm{e}$ & $38.42 \mathrm{~b}-\mathrm{h}$ & 1.40 \\
\hline HD-24 & $70.09 \mathrm{~b}-\mathrm{e}$ & 48.05 ef & $36.01 \mathrm{e}-1$ & 1.45 \\
\hline HD-25 & $66.00 \mathrm{~d}-\mathrm{j}$ & $48.78 \mathrm{~d}-\mathrm{f}$ & $39.63 \mathrm{~b}-\mathrm{h}$ & 1.35 \\
\hline HD-26 & $67.52 \mathrm{c}-\mathrm{h}$ & $49.02 \mathrm{~d}-\mathrm{f}$ & $39.40 \mathrm{~b}-\mathrm{h}$ & 1.37 \\
\hline HD-27 & $73.19 \mathrm{a}-\mathrm{c}$ & $47.46 \mathrm{f}$ & $41.37 \mathrm{a}-\mathrm{d}$ & 1.54 \\
\hline HD-28 & $71.01 \mathrm{a}-\mathrm{d}$ & $48.22 \mathrm{ef}$ & $45.44 \mathrm{a}$ & 1.47 \\
\hline Benino & $69.99 \mathrm{~b}-\mathrm{e}$ & $52.28 \mathrm{a}-\mathrm{d}$ & $39.78 \mathrm{~b}-\mathrm{g}$ & 1.33 \\
\hline $\mathbf{P}$ & $<0.05$ & $<0.05$ & $<0.05$ & $>0.0 .5$ \\
\hline
\end{tabular}

Çalışmada hibrit dolmalık çeşit adaylarında ortalama meyve sap uzunluklarının 30.72-45.44 mm arasında dağılış gösterdiği saptanmıştır (Tablo 3). Dolmalık biber genotipleri içerisinde en kısa meyve sapı uzunluğu HD$6(30.72 \mathrm{~mm})$ genotipinde ölçülmüştür. En uzun meyve sapı uzunluğu ise HD-28 (45.44 mm) çeşit adayında belirlenmiştir. Bunu istatistiksel olarak aynı sınıfta yer alan HD-21 (42.82 mm) ve HD-22 (42.51 mm) genotipleri izlemiştir.

Serada sonbahar ve kış dönemi yetiştiriciliğinde özellikle tüketiciler ve üreticiler tarafından aranılan meyve özelliklerinden birisi de meyve rengidir. Çalışmada dolmalık biber genotiplerinin meyve kabuk renkleri görsel olarak ve dijital renk ölçme aleti ile belirlenmiştir. Yapılan görsel incelemede, renk tonları yönünden dolmalık biber genotipleri arasında belirgin farklılıkların olduğu saptanmıştır. Genotiplere göre meyve renklerinin koyu yeşil, yeşil, açık yeşil ve sarı renk tonlarında olduğu belirlenmiştir. Dolmalık biber genotiplerinin meyve rengi görsel olarak incelendiğinde; 11 genotipin yeşil, 9 genotipin koyu yeşil, 8 genotipin açık yeşil ve 1 genotipin ise sarı renkli olduğu bulunmuştur (Tablo 4).

Dijital renk ölçüm sonuçlarına göre; dolmalık biber genotiplerinin meyve kabuk renklerinde istatistiksel olarak önemli düzeyde farklılıkların olduğu saptanmıştır. Meyve kabuk renk bileşenleri incelendiğinde; L değeri, 41.72 ile 48.14 arasında değişim göstermiştir. En yüksek L değeri (parlaklık), HD-14 (48.14) genotipine aittir. En düşük L değeri ise HD-6 (41.72) genotipinde belirlenmiştir. En yüksek a değeri, HD-15 (16.42) ve en düşük ise HD-26 (13.34) çeşit adayında belirlenmiştir. En yüksek b değerinin ise HD-15 (19.71) genotipinde ve en düşük değer ise istatistiksel olarak aynı sınıfta yer alan HD-26 (13.26) ve HD-28 (13.37) çeşit adaylarına ait olduğu belirlenmiştir. 
Tablo 4. Dolmalık biber genotiplerinde görsel olarak belirlenen meyve kabuk renkleri ve dijital olarak ölçülen L, a, b değerlerine ait sonuçlar

\begin{tabular}{|c|c|c|c|c|}
\hline \multirow[b]{2}{*}{ Genotip } & \multirow[b]{2}{*}{ Görsel } & \multicolumn{3}{|c|}{ Dijital (Minalto Chrometre) } \\
\hline & & $\mathbf{L}$ & $-\mathbf{a}$ & $+\mathbf{b}$ \\
\hline HD-1 & Açık yeşil & $43.57 b-f$ & $-13.98 \mathrm{c}-\mathrm{f}$ & $14.63 \mathrm{c}-\mathrm{e}$ \\
\hline HD-2 & Yeşil & $44.18 \mathrm{~b}-\mathrm{f}$ & $-15.01 \mathrm{a}-\mathrm{f}$ & 16.85 a-e \\
\hline HD-3 & Açık yeşil & $45.13 \mathrm{a}-\mathrm{f}$ & $-15.59 \mathrm{a}-\mathrm{d}$ & $17.18 \mathrm{a}-\mathrm{e}$ \\
\hline HD-4 & Yeşil & $43.72 b-f$ & $-14.49 a-f$ & 15.60 a-e \\
\hline HD-5 & Koyu yeşil & $44.22 \mathrm{~b}-\mathrm{f}$ & $-14.95 \mathrm{a}-\mathrm{f}$ & $17.11 \mathrm{a}-\mathrm{e}$ \\
\hline HD-6 & Yeşil & $41.72 \mathrm{f}$ & $-14.12 b-f$ & $15.00 \mathrm{~b}-\mathrm{e}$ \\
\hline HD-7 & Koyu yeşil & $43.71 \mathrm{~b}-\mathrm{f}$ & $-14.77 \mathrm{a}-\mathrm{f}$ & 15.24 a-e \\
\hline HD-8 & Yeşil & $45.03 \mathrm{a}-\mathrm{f}$ & $-15.25 \mathrm{a}-\mathrm{f}$ & 17.08 a-e \\
\hline HD-9 & Koyu yeşil & $43.96 \mathrm{~b}-\mathrm{f}$ & -15.32 a-e & 16.09 a-e \\
\hline HD-10 & Koyu yeşil & 45.50 a-e & $-15.94 a b$ & $18.10 \mathrm{a}-\mathrm{d}$ \\
\hline HD-11 & Açık yeşil & $46.21 \mathrm{a}-\mathrm{e}$ & $-15.95 a b$ & $18.28 \mathrm{a}-\mathrm{d}$ \\
\hline HD-12 & Koyu yeşil & 44.83 a-f & $-15.26 \mathrm{a}-\mathrm{f}$ & $17.41 \mathrm{a}-\mathrm{e}$ \\
\hline HD-13 & Yeşil & $46.83 \mathrm{ab}$ & $-15.94 a b$ & $19.37 \mathrm{ab}$ \\
\hline HD-14 & Sar1 & $48.14 \mathrm{a}$ & $-14.22 b-f$ & $18.00 \mathrm{a}-\mathrm{d}$ \\
\hline HD-15 & Açık yeşil & $46.38 \mathrm{a}-\mathrm{d}$ & $-16.42 \mathrm{a}$ & $19.71 \mathrm{a}$ \\
\hline HD-16 & Yeşil & $44.39 \mathrm{~b}-\mathrm{f}$ & $-14.65 a-f$ & 16.28 a-e \\
\hline HD-17 & Açık yeşil & $46.63 \mathrm{a}-\mathrm{c}$ & $-15.05 \mathrm{a}-\mathrm{f}$ & $18.78 \mathrm{a}-\mathrm{c}$ \\
\hline HD-18 & Açık yeşil & 45.95 a-e & $-15.68 \mathrm{a}-\mathrm{c}$ & $18.09 \mathrm{a}-\mathrm{d}$ \\
\hline HD-19 & Yeşil & $46.35 \mathrm{a}-\mathrm{e}$ & $-15.14 \mathrm{a}-\mathrm{f}$ & 17.66 a-e \\
\hline HD-20 & Açık yeşil & 43.98 b-f & $-14.46 b-f$ & 15.61 a-e \\
\hline HD-21 & Koyu yeşil & $44.16 b-f$ & $-13.88 c-f$ & $14.27 \mathrm{~d}$ \\
\hline HD-22 & Yeşil & $43.60 \mathrm{~b}-\mathrm{f}$ & $-13.99 c-f$ & $14.33 \mathrm{c}-\mathrm{e}$ \\
\hline HD-23 & Yeşil & $43.73 b-f$ & -13.60 ef & $13.90 \mathrm{de}$ \\
\hline HD-24 & Koyu yeşil & $43.96 \mathrm{~b}-\mathrm{f}$ & $-13.86 c-f$ & $14.08 \mathrm{de}$ \\
\hline HD-25 & Koyu yeşil & $43.11 \mathrm{~d}-\mathrm{f}$ & $-13.72 d-f$ & $13.87 \mathrm{de}$ \\
\hline HD-26 & Açık yeşil & $43.23 \mathrm{c}-\mathrm{f}$ & $-13.34 \mathrm{f}$ & $13.26 \mathrm{e}$ \\
\hline HD-27 & Yeşil & $44.21 \mathrm{~b}-\mathrm{f}$ & $-13.77 \mathrm{c}-\mathrm{f}$ & $14.18 \mathrm{de}$ \\
\hline HD-28 & Koyu yeşil & $43.46 \mathrm{~b}-\mathrm{f}$ & $-13.56 \mathrm{ef}$ & $13.37 \mathrm{e}$ \\
\hline Benino $F_{1}$ & Yeşil & $42.90 \mathrm{ef}$ & -13.54 ef & $14.31 \mathrm{c}-\mathrm{e}$ \\
\hline $\mathbf{P}$ & & $<0.05$ & $<0.05$ & $<0.05$ \\
\hline
\end{tabular}

Meyvede kaliteyi etkileyen en önemli unsurlardan birisi de meyvedeki kuru madde miktarıdır. Dolmalık biber genotiplerinin meyvelerindeki ortalama kuru madde miktarı değerleri incelendiğinde; en yüksek HD-6 (7.95 g) genotipinde olduğu belirlenmiştir. En düşük değer ise HD-3 (5.08 g) genotipinde saptanmıştır. Benino $F_{1}$ çeşidinin meyvelerindeki kuru madde miktarının ise ortalama $5.81 \mathrm{~g}$ olduğu bulunmuştur (Şekil 3).

Dolmalık biberlerde, tüketiciler tarafından aranan diğer bir meyve kalite kriteri ise meyve et kalınlığıdır. Biberde, meyve etinin çok kalın olması ya da çok ince olması istenilen bir pazar kriteri değildir [18]. Araştırma sonucunda; en yüksek meyve et kalınlığına sahip olan genotipin HD-10 (3.84 mm) ve en düşük meyve et kalınlığa ise HD-7 $(2.50 \mathrm{~mm})$ genotipinin sahip olduğu belirlenmiştir (Şekil 4). Benino $\mathrm{F}_{1}$ çeşidinin ortalama meyve et kalınlığı değeri ise $3.05 \mathrm{~mm}$ olarak saptanmıştır. Literatürde dolmalık biber genotiplerinde meyve et kalınlığı değerlerinin 3.0-4.0 mm arasında değiştiği bildirilmiştir [17]. 


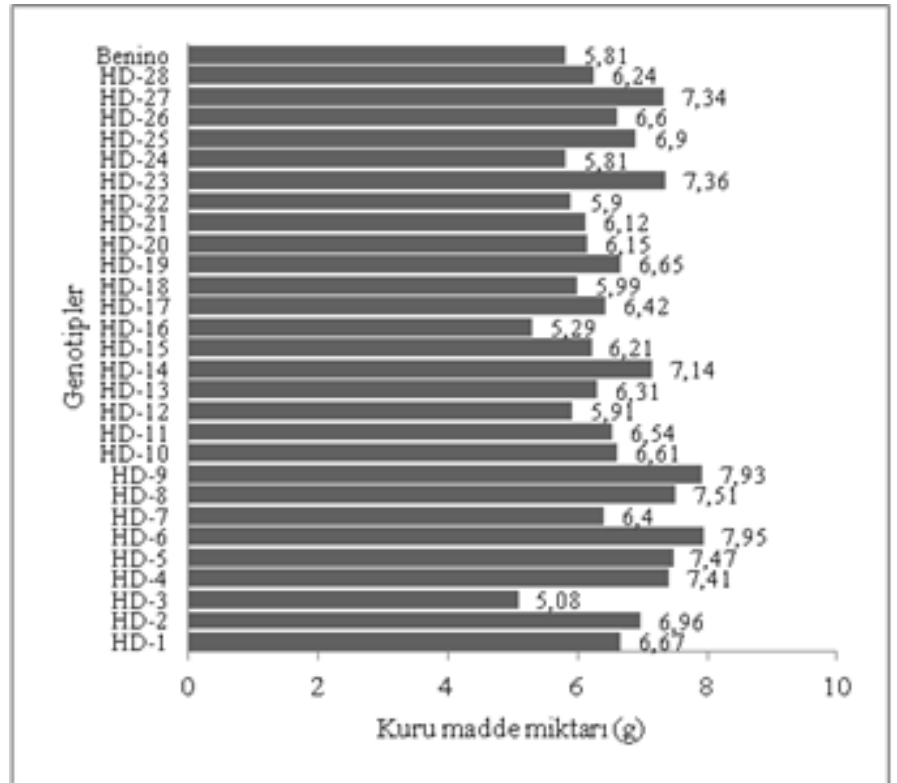

Şekil 3. Dolmalık biber genotiplerinde meyvede ortalama kuru madde miktarı $(\mathrm{g})$ değerlerinin değişimi

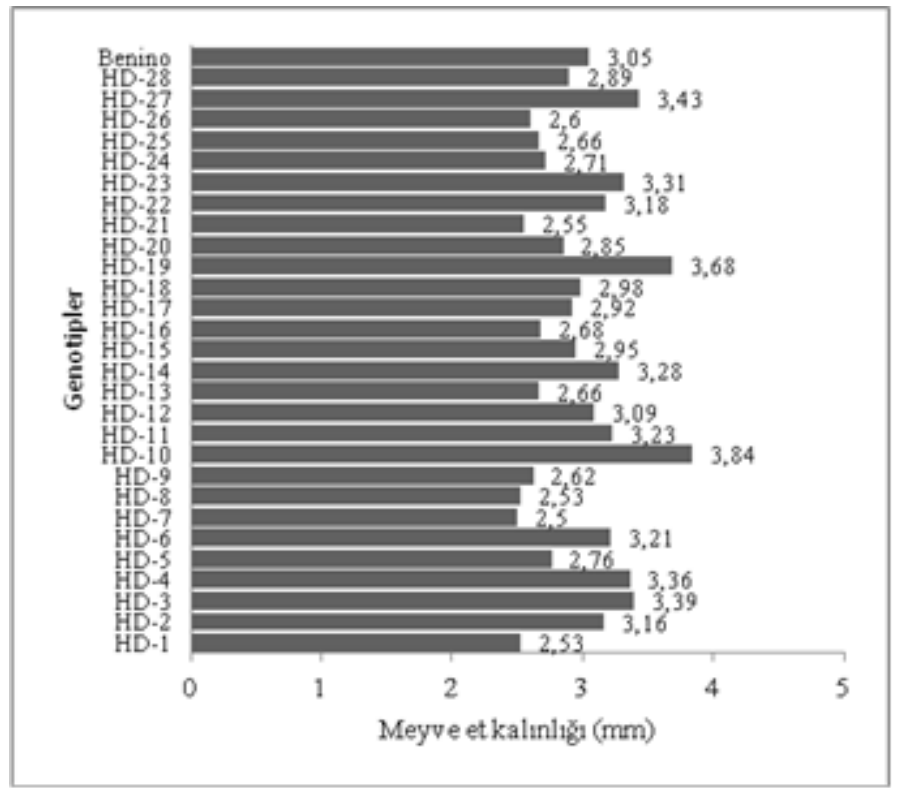

Şekil 4. Dolmalık biber genotiplerinde meyve et kalınlığı $(\mathrm{mm})$ değerlerine ait sonuçlar

Hibrit dolmalık biber genotiplerinin, sonbahar döneminde 1sıtmasız serada meyve verim unsurları yönünden istatistiksel olarak önemli düzeyde farklılıklar gösterdikleri belirlenmiştir (Tablo 5). Isıtmasız serada sonbahar döneminde dolmalık biber genotiplerinde bitki başına ortalama meyve sayılarının, 15.6-30.0 adet arasında dağılış gösterdiği tespit edilmiştir (Tablo 5). Bitki başına en yüksek meyve sayısı, HD-8 (30.0 adet) çeşit adayında belirlenmiştir. Bunu, HD-24 (28.3 adet) genotipi takip etmiştir. Bitki başına en düşük meyve sayısının ise HD-16 (15.6 adet) genotipinde olduğu saptanmıştır. Kontrol Benino $F_{1}$ çeşidinde ise bitki başına meyve sayısının ortalama 16.3 adet olduğu belirlenmiştir. Sonbahar döneminde hibrit dolmalık biber çeşit adaylarının, büyük bir çoğunluğunun, Benino $\mathrm{F}_{1}$ çeşidine göre bitki başına meyve sayılarının daha fazla olduğu tespit edilmiştir. 


\begin{tabular}{|c|c|c|}
\hline & $\begin{array}{l}\text { BŞEÜ Fen Bilimleri Dergisi } \\
8(1), 78-89,2021\end{array}$ & $\begin{array}{r}\text { BSEU Journal of Science } \\
\text { https://doi.org/10.35193/bseufbd.840847 }\end{array}$ \\
\hline & & 2458-7575 (https://dergipark.org.tr/tr/pub/bseufbd) \\
\hline
\end{tabular}

Tablo 5. Dolmalık biber genotiplerinin verim unsurlarına ait sonuçlar

\begin{tabular}{|c|c|c|c|c|}
\hline $\begin{array}{l}\text { Genotip } \\
\text { No }\end{array}$ & $\begin{array}{l}\text { Bitki Başına Meyve } \\
\text { Sayısı (Adet) }\end{array}$ & $\begin{array}{l}\text { Ortalama Meyve } \\
\text { Ağırlığı (g) }\end{array}$ & $\begin{array}{l}\text { Bitki Başına Toplam } \\
\text { Meyve Ağırlığı (g) }\end{array}$ & $\begin{array}{c}\text { Dekara Verim } \\
(\mathrm{kg} / \mathrm{da})\end{array}$ \\
\hline HD-1 & $19.0 \mathrm{c}-\mathrm{e}$ & 50.93 & 967.7 b-d & 3415.5 b-d \\
\hline HD-2 & $20.0 \mathrm{~b}-\mathrm{e}$ & 50.55 & $1011.1 \mathrm{a}-\mathrm{d}$ & 3568.8 a-d \\
\hline HD-3 & $19.3 \mathrm{~b}-\mathrm{e}$ & 48.52 & $936.5 \mathrm{~b}-\mathrm{d}$ & 3305.4 b-d \\
\hline HD-4 & $26.3 \mathrm{a}-\mathrm{c}$ & 48.34 & $1271.5 \mathrm{a}-\mathrm{c}$ & $4487.9 \mathrm{a}-\mathrm{c}$ \\
\hline HD-5 & $17.0 \mathrm{de}$ & 54.74 & 930.7 b-d & $3284.8 \mathrm{~b}-\mathrm{d}$ \\
\hline HD-6 & $19.6 \mathrm{~b}-\mathrm{e}$ & 52.64 & 1031.9 a-d & $3642.3 \mathrm{a}-\mathrm{d}$ \\
\hline HD-7 & $23.3 \mathrm{a}-\mathrm{e}$ & 44.45 & $1035.8 \mathrm{a}-\mathrm{d}$ & $3655.8 \mathrm{a}-\mathrm{d}$ \\
\hline HD-8 & $30.0 \mathrm{a}$ & 48.19 & $1445.7 \mathrm{a}$ & $5102.5 \mathrm{a}$ \\
\hline HD-9 & 20.0 b-e & 55.52 & $1110.3 \mathrm{a}-\mathrm{d}$ & 3919.0 a-d \\
\hline HD-10 & 23.6 a-e & 47.80 & $1128.2 \mathrm{a}-\mathrm{d}$ & 3981.9 a-d \\
\hline HD-11 & $19.3 \mathrm{~b}-\mathrm{e}$ & 51.20 & $988.3 \mathrm{a}-\mathrm{d}$ & $3488.3 \mathrm{a}-\mathrm{d}$ \\
\hline HD-12 & 23.0 a-e & 19.80 & $1145.5 \mathrm{a}-\mathrm{d}$ & $4043.1 \mathrm{a}-\mathrm{d}$ \\
\hline HD-13 & 19.0 c-e & 49.58 & 942.2 b-d & $3325.5 \mathrm{~b}-\mathrm{d}$ \\
\hline HD-14 & $26.3 \mathrm{a}-\mathrm{d}$ & 44.68 & $1175.1 \mathrm{a}-\mathrm{d}$ & $4147.4 \mathrm{a}-\mathrm{d}$ \\
\hline HD-15 & $21.3 \mathrm{a}-\mathrm{e}$ & 49.70 & 1058.8 a-d & $3737.1 \mathrm{a}-\mathrm{d}$ \\
\hline HD-16 & $15.6 \mathrm{e}$ & 46.5 & $725.4 \mathrm{~d}$ & $2560.5 \mathrm{~d}$ \\
\hline HD-17 & 23.0 a-e & 47.33 & 1088.6 a-d & $3842.4 \mathrm{a}-\mathrm{d}$ \\
\hline HD-18 & $22.6 \mathrm{a}-\mathrm{e}$ & 50.00 & $1130.2 \mathrm{a}-\mathrm{d}$ & 3988.9 a-d \\
\hline HD-19 & $22.3 \mathrm{a}-\mathrm{e}$ & 52.32 & $1166.9 \mathrm{a}-\mathrm{d}$ & 4118.6 a-d \\
\hline HD-20 & $27.0 \mathrm{a}-\mathrm{c}$ & 49.61 & $1339.7 \mathrm{ab}$ & $4728.4 \mathrm{ab}$ \\
\hline HD-21 & $18.0 \mathrm{c}-\mathrm{e}$ & 50.24 & 904.4 b-d & $3192.1 \mathrm{~b}-\mathrm{d}$ \\
\hline HD-22 & 22.6 a-e & 49.26 & $1113.5 \mathrm{a}-\mathrm{d}$ & $3930.3 \mathrm{a}-\mathrm{d}$ \\
\hline HD-23 & $21.0 \mathrm{a}-\mathrm{e}$ & 49.2 & $1033.2 \mathrm{a}-\mathrm{d}$ & 3646.7 a-d \\
\hline HD-24 & $28.3 \mathrm{ab}$ & 45.68 & $1292.9 \mathrm{ab}$ & $4563.4 \mathrm{ab}$ \\
\hline HD-25 & $21.3 \mathrm{a}-\mathrm{e}$ & 46.81 & $997.25 \mathrm{a}-\mathrm{d}$ & $3519.7 \mathrm{a}-\mathrm{d}$ \\
\hline HD-26 & $21.3 \mathrm{a}-\mathrm{e}$ & 46.3 & $986.9 \mathrm{a}-\mathrm{d}$ & $3483.2 \mathrm{a}-\mathrm{d}$ \\
\hline HD-27 & 23.0 a-e & 48.75 & $1121.4 \mathrm{a}-\mathrm{d}$ & 3957.9 a-d \\
\hline HD-28 & $22.3 \mathrm{a}-\mathrm{e}$ & 48.56 & 1082.9 a-d & 3822.3 a-d \\
\hline Benino $F_{1}$ & $16.3 \mathrm{e}$ & 49.38 & $805.0 \mathrm{~cd}$ & $2841.2 \mathrm{~cd}$ \\
\hline $\mathbf{P}$ & $<0.05$ & $>0.05$ & $<0.05$ & $<0.05$ \\
\hline
\end{tabular}

Dolmalık biberde meyve büyüklüğü, tüketiciler tarafından aranılan önemli bir pazar kriteridir. Tüketiciler meyvelerin çok büyük olmasını arzu etmemektedir [18]. Ortalama meyve ağırlığı yönünden hibrit dolmalık biber genotipleri arasında istatistiksel olarak farklılık tespit edilmemiştir (Tablo 5). En yüksek ortalama meyve ağırlığı değerleri sırasıyla; HD-9 (55.52 g) ve HD-5 (54.74 g) çeşit adaylarında belirlenmiştir. Yapılan diğer araştırmalarda, dolmalık biber çeşitlerinde ortalama meyve ağırlığının, 29.2 g-33.3 g arasında veya 34.34 g-64.34 $\mathrm{g}$ arasında değişim gösterdiği bildirilmiştir [16,17]. Araştırma sonuçları, genotiplere göre değişmekle birlikte belirtilen literatürler ile genel olarak uyumluluk göstermiştir.

Bitki başına toplam meyve ağırlığı değerleri karşılaştırıldığında, en yüksek verim değeri HD-8 (1445.7 g) çeşit adayından elde edilmiştir. En düşük verim değeri ise HD-16 (725.4 g) genotipinde saptanmıştır. Dekara verim değerlerinin dolmalık biber genotiplerinde $2560.5 \mathrm{~kg}$ ile $5102.5 \mathrm{~kg}$ arasında değişim gösterdiği saptanmıştır (Tablo 5). En yüksek dekara verim değeri, HD-8 (5102.5 kg) genotipinde ve en düşük verim ise HD-16 (2560.5 kg) genotipinde tespit edilmiştir. Araştırma sonucunda, Samsun ekolojik koşullarında 1sıtmasız serada hibrit dolmalık biber çeşit adaylarının büyük bir çoğunluğunun dekara verim değerlerinin kontrol çeşitten (Benino $\left.F_{1}\right)$ daha yüksek olduğu belirlenmiştir. Bu sonuç, belirtilen hibrit adaylarının ticari üretimde yer bulması açısından oldukça önemlidir. Biber yetiştiriciliğinde çeşitlerin verim kapasiteleri, yetiştirme mevsimi ve vejetasyon süresi, yetiştirildiği ortam, gübreleme, sulama, budama, toprak işleme, hastalık ve zararlılarla savaşım, toprağın fiziksel ve biyolojik yapısı vb. faktörlere göre değişkenlik göstermektedir [19]. Literatürde serada dolmalık biber yetiştiriciliğinde $26.60 \mathrm{t}$ /ha verim elde edildiği belirtilmiştir [20]. Araştırma sonuçları ile belirtilen literatürlere ait verim değerleri arasındaki farklılık, genotip×çevre interaksiyonundan kaynaklanmaktadır. 


\section{SONUÇ}

Bitkilerin düşük sıcaklıklarda zararlanma düzeyleri birçok faktöre bağlıdır. Bunlar bitkilerin genotipik yapısı, kalıtsal nitelikleri, bitki bünyesindeki içsel maddeler ve biyokimyasal değişimler, düşük sıcaklığın derecesi, düşük sıcaklığın ortaya çıkış zamanı, sıcaklığın düşüş hızı ve bitkiye uygulanan kültürel uygulamalar olarak sayılabilir. Bu faktörlerin her birinin soğuğa dayanım mekanizmasında ayrı bir fizyolojik önemi vardır. Bunlar çoğu zaman karşılıklı etkileşerek bitkinin soğuğa dayanımını sağlamakta veya duyarlılığını artırmaktadır [21,22]. Düşük sıcaklık stresine dayanıklılık yönünden bitki türleri arasında genotipik düzeyde farklılıklar bulunmaktadır. Bu nedenle, son yıllarda hem klasik dayanıklılık ıslahı çalışmalarında ve hem de fizyolojik ve moleküler düzeydeki araştırmalarda düşük sıcaklık stresine tolerant yeni çeşitlerin geliştirilmesi ve toleranslıkta rol alan mekanizmaların belirlenmesi çalışmalarına daha fazla önem verilmeye başlanmıştır.

Bu çalışmada özel sektör ile birlikte yürütülen "Dolmalık biber genotiplerinde düşük sıcaklığa dayanıklı hibrit çeşit geliştirme 1slah programı” sonucunda geliştirilen hibrit dolmalık biber çeşit adaylarının meyve kalitesi ve verim unsurları yönünden performansları ayrıntılı olarak incelenmiştir. Araştırmada incelenen tüm parametreler birlikte değerlendirildiğinde; HD-4, HD-8 ve HD-24 genotiplerinin düşük sıcaklığa dayanıklı veya tolerant olduğu, takoz meyve oluşumunun görülmediği ve sonbahar yetiştiriciliği için en uygun hibrit dolmalık biber çeşit adayları olduğu belirlenmiştir. Belirtilen hibrit dolmalık çeşit adaylarının Antalya'da ısıtmasız seralarda kış dönemi yetiştiriciliğinde performanslarının belirlenmesine yönelik çalışmalar halen firma tarafından yürütülmektedir. Hem sonbahar ve hem de kış dönemi yetiştiriciliğinde öne çıkan dolmalık hibrit biber çeşit adaylarının, firma tarafından çeşit tescilleri (Standart Tohumluk Kaydı) önümüzdeki dönem yapılacaktır. Araştırma sonucunda düşük sıcaklığa tolerant veya dayanıklı yerli hibrit dolmalık biber çeşitlerinin geliştirilmesiyle hem biber tohumluk ithalatı azalacak ve hem de ısıtma masrafı olmadan düşük sıcaklığa tolerant çeşitlerin kullanımı ile daha ucuza, geniş bir üretim periyodunda yetiştiricilik yapılması mümkün olabilecektir.

\section{TEŞEKKÜR}

Araştırma, Sanayi ile İş Birliği Araştırmalarını Destekleme Programı (1903 kodlu projeler) kapsamında Ondokuz Mayıs Üniversitesi tarafından PYO.ZRT.1903.16.001 proje numarası ile desteklenmiştir. Projenin yürütülmesinde maddi katkıları için Ondokuz Mayıs Üniversitesi ve Genetika Tohumculuk Firmasına teşekkür ederiz. Bu çalışma, Yükseköğretim Kurulu 637280 numaralı Rüveyda Özgen'in yüksek lisans tezinden üretilmiştir.

\section{KAYNAKLAR}

[1] Eşiyok, D. (2012). Kışlık ve Yazlık Sebze Yetiştiriciliği. Ege Üniversitesi, Ziraat Fakültesi, Bahçe Bitkileri Bölümü, 410, Meta Basım Matbaacılık, İzmir.

[2] Karaağaç, O. (2004). Biber Çeşit Islahı. Yüksek Lisans Semineri, Ondokuz Mayıs Üniversitesi, Fen Bilimleri Enstitüsü, Samsun.

[3] Şalk, A., Arın, L., Deveci, M. \& Polat, S. (2008). Özel Sebzecilik. Namık Kemal Üniversitesi, Ziraat Fakültesi, Bahçe Bitkileri Bölümü. Sevil Cilt Evi ve Matbaası, Tekirdağ.

[4] TÜİK, (2019). Türkiye İstatistik Kurumu, http//www.tuik.gov.tr, (Erişim tarihi: 28.04.2020).

[5] Büyük İ., Soydam Aydın, S. \& Aras, S. (2012). Bitkilerin stres koşullarına verdiği moleküler cevaplar. Türk Hijyen ve Deneysel Biyoloji Dergisi, 69, 2, 97-110.

[6] Wien, H. C. (1997). The Physiology of Vegetable Crops. Department of Fruit and Vegetable Science, Cornell University, USA 259 -293.

[7] Abak, K. (1995). Efficiency of bumble bees on the yield and quality of eggplant and tomato grown in unheated glasshouses. I International Symposium on Solanacea for Fresh Market, Malaga, Spain, 412.

[8] Sánchez, E. G., Heuvelink, E. \& Stanghellini, C. (2015). Physiological processes affected by low night temperatures in sweet pepper plants. Procedia Environmental Sciences, 29, 253-254.

[9] Keleş, D. (2007). Farklı biber genotiplerinin karakterizasyonu ve düşük sıcaklığa tolerans. Doktora Tezi, Çukurova Üniversitesi, Fen Bilimleri Enstitüsü, Adana.

[10] Eti, S. (1996). Döllenme Biyolojisi Ders Notları, Çukurova Üniversitesi, Ziraat Fakültesi, Bahçe Bitkileri Bölümü, Adana.

[11] George, R. A. T. (1985). Vegetable Seed Production. Longman Group Limited, London and New York, 318.

[12] Turan, Ö. \& Ekmekçi, Y. (2008). Soğuk stresinin bitkiler üzerine etkileri ve tolerans mekanizmaları. Anadolu Üniversitesi Bilim ve Teknoloji Dergisi, 9(2), 177-198. 
[13] Anonim, (2018). Karadeniz Tarımsal Araştırma Enstitüsü Müdürlüğü. https://arastirma.tarimorman.gov.tr/ktae.

[14] Aydoğan, A. (2017). Örtüaltı biber (Capsicum annuum L. var. longum cvs “Asi $F_{1}$ ” ve "Görkem $F_{1}$ ") yetiştiriciliğinde aşılı fide kullanımının bitki gelişimi, verim ve meyve kalitesi üzerine etkileri. Yüksek Lisans Tezi, Adnan Menderes Üniversitesi, Fen Bilimleri Enstitüsü, Aydın.

[15] Mutlu, S., Haytaoğlu, M. A., Kır, A. \& İçer, B. (2009). Ulusal Gen Bankası Biber (Capsicum annuum L.) Materyalinde Morfolojik Karakterizasyon. Anadolu Ege Tarımsal Araştırma Enstitüsü Dergisi, 1(1), 63-91.

[16] Oral, E. (2019). Dolma biberde (Capsicum annuum L.) sürgün budamasının verim ve kalite üzerine etkileri. Yüksek Lisans Tezi, Namık Kemal Üniversitesi, Fen Bilimleri Enstitüsü, Tekirdağ.

[17] Binbir, S. (2010). Bazı yerel biber (Capsicum annuum L.) populasyonlarında karakterizasyon çalışmaları. Doktora Tezi, Adnan Menderes Üniversitesi, Fen Bilimleri Enstitüsü, Aydın.

[18] Karaağaç, O. (2006). Bafra Kırmızı Biber Gen Kaynaklarının (Capsicum annuum var. conoides Mill.) Karakterizasyonu ve Değerlendirilmesi. Yüksek Lisans Tezi, Ondokuz Mayıs Üniversitesi, Fen Bilimleri Enstitüsü, Samsun.

[19] Aybak, H. Ç. (2002). Biber Yetiştiriciliği. Hasad Yayıncılık, 160s, İstanbul.

[20] Awalin, S., Shahjahan, M., Chandra, Roy, A., Akter, A. \& Kabir, M. H. (2017). Response of bell pepper (Capsicum annuum L.) to foliar feeding with micro nutrients and shoot pruning. Journal of Agriculture and Ecology Research International, 11(3), 1-8.

[21] Eriş, A. (1985). Bahçe Bitkileri Fizyolojisi. Uludağ Üniversitesi Ziraat Fakültesi Ders Notları, 11, Bursa.

[22] Günay, A. (1992). Özel Sebze Yetiştiriciliği. Cilt II. Ankara Üniversitesi Ziraat Fakültesi Bahçe Bitkileri Bölümü, Çă̆ yayıncılık, Ankara. 